НАУКОВИЙ ВІСНИК

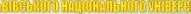

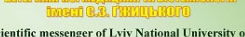

eientific messegger of Lviv National University
Veterinary Medicine and Bioteclinologies

rownon

Tा है की

1

Tом 21 № 91

2019
Науковий вісник Дьвівського національного університету ветеринарної медицини та біотехнологій імені С.3. Гжицького. Серія: Сільськогосподарські науки

\author{
Scientific Messenger of Lviv National University
} of Veterinary Medicine and Biotechnologies. Series: Agricultural sciences

ISSN 2519-2698 print

https://nvlvet.com.ua/index.php/agriculture

doi: $10.32718 /$ nvlvet-a9103

UDC 543. 3: 628. 1

\title{
Investigation of Causes and Influences of Soil Acidity on Crop Yields in Kozova District, Ternopil Region
}

\author{
N.M. Glovyn, O.V. Pavliv
}

Separated Subdivision of National University of Life and Environmental Sciences of Ukraine "Berezhany Agritechnical Institute”, Berezhany, Ukraine

Article info

Received 03.09.2019

Received in revised form 02.10 .2019

Accepted 04.10.2019

Separated subdivision of National University of Life and

Environmental Sciences of Ukraine "Berezhany Agrotechnical Institute", Academichna Str., 20,

Berezhany, Ternopil region, 47501, Ukraine.

Tel.: +38-067-208-60-99

E-mail:nadiaglovin@gmail.com
Glovyn, N.M., \& Pavliv, O.V. (2019). Investigation of Causes and Influences of Soil Acidity on Crop Yields in Kozova District, Ternopil Region. Scientific Messenger of Lviv National University of Veterinary Medicine and Biotechnologies. Series: Agricultural sciences, 21(91), 16-20. doi: $10.32718 /$ nvlvet-a9103

The paper covers the causes of occurrence and the methods of investigating soil acidity in Kozova destrict, Ternopil region. It is a highly topical issue, since increased soil acidity negatively influences the growth and the development of most cultivated crops and affects favourable microbiological soil properties. Soil acidity is caused by hydroions that are formed under the dissociation of acids and hydrolytic acid salts and are absorbed by the smallest soil particles - colloids, which can go into interstitial water. The increased soil acidity, which is a limiting factor for the biodiversity of a particular area and interferes healthy plant development, is an important agricultural problem. It can cause the decrease of crop yields as well as plant diseases. That is why, farmers should be aware of the type and the peculiarities of the soil present on their lots and take into account and regulate $\mathrm{pH}$ values when cultivating various agricultural crops. Soil acidity is considered to be acceptable for the healthy growth and development of plants, if it falls within the limits of $p H$ 6.5-7.5. It has been determined that the application of mineral fertilizers without limestone materials causes acidification of typical black soils. If there is a long-term use of the increased amounts of mineral fertilizers, there is an increase of the active acidity observed. The application of nitrogenous fertilizers increases soil active acidity even more compared to the use of phosphate potassium fertilizers. Soil exhaustion prevention techniques have been substantiated. The methods of determining soil acidity have been considered. A potentiometric method is the most wide-spread in terms of determining soil acidity level, since it is highly sensitive and accurate. Soil acidity has been experimentally determined by potentiometry using TSINAO method (GOST 26483-85) and hydrolytically using Kapenn method (GOST 26212-91). Statistical data processing has been performed. The weighted-average acidity index $p H$ salt. is 6.3 and the hydrolytic acidity is $1.77 \mathrm{mg}-$ acs $/ 100 \mathrm{~g}$ of soil, $\mathrm{pH}$ salt. is 5.9 and hydrolytic acidity is $1.92 \mathrm{mg}-$ acs/100g of soil. It shows that plants can grow and develop well in this soil. Scientific and production experience suggests that the yield from acid soils decreases for 15-20\%. The scientific agro-ecological approach, that is the calculation of the balance of nutrients and humus depending on the kind of the cultivated crop as well as physical, chamical and bilological soil characteristics and well-timed liming, can provide the necessary level of nutrients in the soil of agricultural enterprises. In order to provide fertile soil and improve agro-ecological conditions of the soil in Kozova district, it is necessary to provide annual application of nutrients using organic and mineral fertilizers with the optimal ratio of nitrogen, phosphorus, potassium and by liming acid soils. Currently, it is very important to apply organic agriculture, which can improve the quality and the competitiveness of agricultural products. Scientific investigations on every crop have determined the optimal $\mathrm{pH}$ level and its value depends on the soil and the climatic conditions, the type of soils, their particle-size distribution and the state of cultivation. Soil acidity is one of the factors that influence the decrease of yields, especially the yields of those crops that require great amounts of potassium and magnesium for their healthy growth.

Key words: soil acidity, pH medium, de-calcination, agro-ecological estimation, humus. 


\title{
Дослідження причин виникнення та впливу кислотності грунтів на урожайність сільськогосподарських культур агрогосподарств Козівського району Тернопільської області
}

\author{
Н.М. Гловин, О.В. Павлів
}

Відокремлений підрозділ Національного університету біоресурсів $і$ природокористування Украӥни “Бережанський агротехнічний інститут”, м. Бережани, Україна

\begin{abstract}
У статті наведено причини виникнення та методи дослідження кислотності трунтів агрогосподарств Козівського району Тернопільської області. Актуальність дослідження є у глобальній проблемі підвищеної кислотності сільськогосподарських земель, що має негативний вплив на фізіологічне функиіонування культурних рослин, а також не сприяє утворенню мікробіологічної флори у трунті. Підзолисті трунти відрізняються фізичними і хімічними властивостями через наявність у їх трунтовому розчині комплексів іонів водню та алюмінію. Внаслідок руйнівної дї водню поглинаючий комплекс кількісно зменшується, а залишок являється ненасиченим основами. Такий грунт обмежується колоїдами, перегноєм та поживними речовинами. Все ие негативно відбивається на розвитку сільськогосподарських культур. Тому аграрники повинні знати тип кислотності трунту на землях, які обробляють, його особливості, брати до уваги значення $\mathrm{pH}$, що властиві певному виду культурних рослин. Кислотність трунту допускається для висаджування сільськогосподарських рослин, якщо вона має показники $\mathrm{pH}$ 6,5-7,5. Досліджено, що підживлення сільськогосподарських земель хімічними засобами без вапнякових матеріалів прискорює утворення кислих трунтів. Якщо вносити у трунт тривалий період збільшені норми мінеральних добрив, тоді буде спостерігатися актуальна кислотність. Внаслідок аналізу досліджень доведено, ще нітратні мінеральні добрива посилюють активну кислотність грунту на відміну від фосфорно-калійних добрив. Розглянуто методи визначення кислотності трунту, а саме: ступінь кислотності (pH) - потенціометрично за методом ЦІНАО (ГОСТ 26483-85) і гідролітична за методом Капенна - (ГОСТ 26212-91). Лише науковий агроекологічний підхід, а саме - розрахунок балансу поживних речовин та гумусу залежно від вирочуваної сільськогосподарської культури, а також фізичних, хімічних $i$ біологічних характеристик трунту, вчасне вапнування забезпечать підтримку рівня поживних речовин у трунтах агрогосподарств. Щоб відновити та тривалий період підтримувати родючість сільськогосподарських земель Козівського району необхідно своєчасно підживлювати поживними речовинами з органічними і мінеральними добривами, що містять Азот, Фосфор, Калій та здійснювати вапнування кислих трунтів. Не мени актуальним для зменшення кислотності трунту є запровадження органічного вирощування сільськогосподарських культур. У статті запропоновано дані наукових досліджень щодо оптимального інтервалу рН для кожної сільськогосподарської культури, значення якого залежить від трунтово-кліматичних умов, типу трунтів, ӥх гранулометричного складу, стану окультуреності.
\end{abstract}

Ключові слова: кислотність трунту, середовище $р Н$, декальцинація, агроекологічна оцінка, гумус.

\section{Вступ}

Сільське господарство має більший вплив на природне середовище, ніж будь-яка інша галузь господарства. Причина цього в тому, що сільське господарство вимагає величезних площ. В результаті зазнають змін природні ландшафти, відбувається заміна природної рослинності на сільськогосподарських угіддях. На жаль, сільськогосподарські ландшафти є нестійкими, адже обробка (опушення) грунту, особливо із застосуванням відвального плуга, застосування мінеральних добрив і отрутохімікатів призводить до ряду локальних і регіональних екологічних проблем - дегуміфікації, засолення грунтів, виникнення кислотності земель, що призводить до втрати родючості. 3 погляду сільськогосподарського виробництва висока якість грунту означає забезпечення високої продуктивності виробництва без істотної його деградації й забруднення навколишнього середовища. Основними причинами, що викликають підкислення, $є$ кислотні опади, обмежене використання агрогосподарствами органічних добрив, нецільове призначення мінеральних добрив та хімічних засобів у традиційних аграрних господарствах. Тому, вторинне підкислення грунтів має в основному антропогенне походження.

На сучасному етапі будь-який господар при плануванні вирощування певної сільськогосподарської культури повинен мати інформацію про тип грунту, його актуальну, обмінну та гідролітичну кислотність. Тематика збільшеної кислотності сільськогосподарсь- ких земель зацікавила багатьох сучасних науковців (М.M. Городній, М.М. Гладюк, С.Г. Самохвалов, В.Г. Смирнов, I.I. Назаренко). Реакція рН грунту має фізіологічний вплив на ріст та розвиток рослин, мікробіологічні, хімічні та біохімічні процеси. Зрозуміло, що усі поживні речовини надходять до рослини у доступній для останньої йонній формі, розчинній у грунтовому розчині. Але досліджено чинники, які можуть обмежувати їх доступність, зокрема, реакція грунтового розчину або $\mathrm{pH}$. Значення $\mathrm{pH}$ грунтового розчину може бути кислим (менше 7), нейтральним (рівне 7), лужним (більше 7). Значення грунту $(\mathrm{pH}<5,5)$ зменшує надходження до рослин азоту, фосфору, кальцію, магнію і прискорює проникнення у рослини заліза, алюмінію і марганцю, які можуть мати токсичну дію. У кислому середовищі у 3-8 разів підвищується накопичення в рослинах радіонуклідів і важких металів. У рослинах, які ростуть на кислих грунтах, погіршується процес фотосинтезу. На лужних (засолених) грунтах $(\mathrm{pH}>7,0)$, навпаки, знижується ймовірність надходження у рослини макроелементів Заліза, Марганцю, Фосфору, Міді, Бору та більшості мікроелементів (Hudz, 2007). Крім того, кисла чи лужна реакція грунтового розчину негативно впливає на інші властивості грунтів. У кислих грунтах порушуються такі його фізико-хімічні властивості: погіршуються фільтраційна здатність, капілярність та проникність; діяльність корисних мікроорганізмів, що сприяють розкладанню гною, торфу тощо; засвоєння бобовими культурами азоту з повітря; впливає на 
біогеохімічні процеси кругообігу речовин: азоту, фосфору, у доступні для рослин йонній формі. Процес нітрифікації вимагає рН 6,5-7,2. На кислих грунтах сам процес нітрифікації дуже повільний, що автоматично переходить у сповільнення при перетворенні амонію в нітратний азот - доступний для рослин. Крім того, занадто висока концентрація азоту в грунті у вигляді аміаку може стати фітотоксичним до рослин, особливо на ранніх стадіях розвитку (Andriichuk, 2002; Semchyk, 2003; Paranjak et al., 2019).

Мета $і$ завдання дослідження: одним із етапів вирішення зазначених проблем $є$ визначення якісного стану грунтового покриву, який використовується для потреб сільськогосподарського виробництва. Цього можна досягти визначаючи агрохімічні показники грунтів. У зв'язку з цим потрібно провести експериментальні дослідження, які дадуть змогу визначити якісний стан земель і підвищити продуктивність кормових угідь та ефективне використання грунтових ресурсів.

\section{Матеріал та методи досліджень}

Об'єкт досліджень був грунтовий покрив сільськогосподарських угідь в господарстві ТзОВ “Вікторія92” Козівського району Тернопільської області. У нашому дослідженні ми скористались потенціометричним методом аналізу визначення кислотності грунту, тому що він високочутливий і точний. Для обстеження грунтів сільськогосподарських підприємств Тернопільської області Козівського району ТзОВ “Вікторія92” використано результати досліджень, проведених відповідно до вимог керівних нормативних документів, методичних вказівок, рекомендацій ДСТУ, ГОСТів та ТУ. Відбір грунтових зразків проводили згідно з методикою суцільного грунтово-агрохімічного моніторингу сільськогосподарських угідь України (1994) (Doklad Konferencii OON..., 1993). Агрохімічні показники грунтів визначали за загальноприйнятими методиками: вміст гумусу (органічної речовини) - за методом Тюріна в модифікації Сімаков (ДСТУ 4289: 2004); вміст лужногідролізованого азоту - за методом Корнфілда згідно з “Метод, указаниями по определению щелочногидролизуемого азота в почве, М., 1985"; рухомих форм фосфору та обмінного калію за методом Чирікова (ДСТУ 4115-2002); ступінь кислотності $(\mathrm{pH})$ - потенціометрично за методом ЦІНАО (ГОСТ 26483-85) і гідролітично за методом Капенна (ГОСТ 26212-91).

\section{Результати та їх обговорення}

Для виконання експериментальних досліджень, які дадуть змогу визначити якісний стан земель, стан грунтового покриву, що використовується для потреб сільськогосподарського виробництва, було обрано земельні ділянки сільськогосподарського призначення. Здатність грунту забезпечувати рослини поживними речовинами характеризують агрохімічні параметри родючості земель. Агроекологічна оцінка дос- ліджуваної території проводилася за вмістом гумусу, реакцією грунтового розчину та основних елементів живлення. Рівень родючості грунтів оцінюється насамперед за вмістом органічної речовини (Ryzhuk \& Lisovyi, 2003). Чим більше гумусу в грунті, тим він багатший на основні елементи живлення, адже в ньому сконцентровано 92-98\% Азоту, 60\% Фосфору та значна кількість інших макро- і мікроелементів (Horodnyi, 2004). Одним 3 показників раціонального ведення землеробства в межах окремого господарства і загалом у державі, відповідно до закону повернення, $\epsilon$ баланс таких дефіцитних, біологічно важливих елементів у грунті, як Нітроген, Фосфор і Калій. Проведені дослідження дають змогу запропонувати проектним установам і виробництву досить обгрунтовану систему показників еталонного грунту. Звичайно, за еталон (стандарт) приймається оптимальне значення діагностичного показника, який оцінюється в 100 балів, що цілком відповідає одному з основних екологічних законів землеробства - закону оптимуму. Стандарти (еталони) для мінеральних грунтів: макроелементи: для Нітрогену - 225 мг/кг за Корнфілдом, 100 мг/кг - за Тюріним Кононовою; для рухомого Фосфору - 250 мг/кг за Кірсановим, 200 мг/кг - за Чіріковим, 60 мг/кг - за Мачігіним; - для обмінного Калію - 170 мг/кг за Кірсановим, 200 мг/кг за Чіріковим, 400 мг/кг за Мачігіним. С.А. Балюк, Р.С. Трускавецький, Ю.Л. Цапко та ін. (2012) розробили методику групування грунтів за ступенем кислотності та лужності, а також оптимальну реакцію $(\mathrm{pH})$ грунтового середовища для більшості сільськогосподарських культур (Vidnoshennia silskohospodarskykh kultur do reaktsii gruntu).

Земельні ділянки розташовані межах населених пунктів с. Вікторівка, с. Плотича Козівського району Тернопільської області. У земельному фонді раніше згаданого господарства переважають темно-сірі опідзолені грунти. Агрохімічне обстеження грунтів у фермерському господарстві “Вікторія-92" проведено на площі 300,0 гектарів, для відбору зразків грунту на агрономічне дослідження поля були розбиті на елементарні ділянки розміром 9-10 га. 3 кожної такої ділянки відібрано один змішаний зразок, який одержано із 20-25-ти індивідуальних проб, взятих по осі елементарної ділянки на глибину 25-30 см (Patyka and Tarariko, 2002). Градація за ступенем забезпеченості грунтів агрохімічними показниками затверджена Центрдержродючості в 2016 році (табл. 1). У результаті відбору зразків на агрохімічне дослідження в Тернопільську філію державної установи “Інститут охорони грунтів України" отримано результати агрохімічних показників грунтів досліджуваних сільськогосподарських угідь господарств Козівського району Тернопільської області (табл. 3). Гумус як найбільш репрезентативний та стійкий агрохімічний показник найбільшою мірою відображає родючість грунту. Нами було проведено порівняння результатів середньозважених показників вмісту поживних речовин і ступеня кислотності досліджуваного господарства (табл. 1). 


\section{Таблиця 1}

Середньозважені показники вмісту поживних речовин і ступеня кислотності у господарстві ТзОВ “Вікторія92”

\begin{tabular}{|c|c|c|c|c|c|c|c|c|}
\hline \multirow{2}{*}{$\begin{array}{c}\text { № } \\
\text { поля }\end{array}$} & \multirow{2}{*}{$\begin{array}{c}\text { № } \\
\text { ділянки }\end{array}$} & \multirow{2}{*}{$\begin{array}{c}\text { Обстежена } \\
\text { площа, га }\end{array}$} & \multicolumn{3}{|c|}{ Вміст мг/кг грунту } & \multicolumn{2}{|c|}{ Кислотність } & \multirow{2}{*}{$\begin{array}{c}\text { Вміст } \\
\text { гумусу, \% }\end{array}$} \\
\hline & & & $\mathrm{N}$ & $\mathrm{P}$ & $\mathrm{K}$ & pH сольове & Гідрол.мг/100 г грунту & \\
\hline 1 & 1 & 50,50 & 133 & 74 & 123 & 6,3 & 1,81 & 2,35 \\
\hline 2 & 1 & 80,40 & 124 & 62 & 120 & 6,4 & 1,62 & 2,48 \\
\hline 3 & 1 & 29,60 & 138 & 113 & 131 & 6,6 & 1,37 & 2,40 \\
\hline 4 & 1 & 9,70 & 136 & 77 & 145 & 6,3 & 1,74 & 1,86 \\
\hline 5 & 1 & 13,30 & 130 & 80 & 165 & 6,4 & 1,63 & 2,24 \\
\hline 6 & 1 & 24,70 & 144 & 57 & 161 & 5,4 & 3,26 & 2,40 \\
\hline 7 & 1 & 13,1 & 125 & 38 & 158 & 5,8 & 2,46 & 2,34 \\
\hline 9 & 1 & 22,50 & 144 & 35 & 143 & 6,2 & 1,90 & 2,00 \\
\hline 10 & 1 & 18,80 & 85 & 40 & 111 & 6,0 & 2,07 & 2,35 \\
\hline 11 & 1 & 16,00 & 132 & 109 & 105 & 7,0 & 0,95 & 2,72 \\
\hline 12 & 1 & 25,00 & 99 & 74 & 70 & 6,9 & 1,08 & 2,85 \\
\hline Всьог & сподарству & 300,0 & 127 & 69 & 125 & 6,3 & 1,77 & 2,41 \\
\hline
\end{tabular}

За ступенем кислотності в фермерському господарстві “Вікторія-92” виявлено, що на площі 24,7 га (7,98\%) грунти слабокислі: (рН сол. 5,1-5,5), близькі до нейтральних на площі 31,9 га $(10,3 \%)$, (pH сол. 5,6-6,0) та нейтральні - 253,0 га $(81,7 \%)$ ( $\mathrm{pH}$ сол. $>6,0)$.

\section{Таблиця 2}

Ступінь кислотності грунту залежно від $\mathrm{pH}$ сольової витяжки

\begin{tabular}{cc}
\hline $\begin{array}{c}\text { Значення } \mathrm{pH} \text { сольової } \\
\text { витяжки }\end{array}$ & $\begin{array}{c}\text { Ступінь кислотності } \\
\text { грунту }\end{array}$ \\
\hline $3-4$ & Сильнокислий \\
$4-5$ & Кислий \\
$5-6$ & Слабокислий \\
біля 7 & Нейтральний \\
$7-8$ & Слаболужний \\
$8-9$ & Лужний \\
\hline
\end{tabular}

На території досліджуваних земель розповсюджені грунти $з$ реакцією грунтового розчину від слабокислих до нейтральних. Середньозважений показник кислотності рН сол. - 6,3, а гідролітична кислотність 1,77 мг-екв/100 г грунту (табл. 1). Оскільки сільськогосподарське виробництво зосереджене на цих землях, то і мова піде про них. Кислі та близькі до нейтральних грунти для оптимізації росту рослин потребують вапнування. Кислотність пов'язана з генезисом грунту. Вона створює певні негативні властивості грунту. В той же час кожен грунт має можливість протистояти зміні кислотності в той чи інший бік. I тому ми спостерігаємо, що навіть застосовуючи вапнування, через певний проміжок часу кислі грунти знову стають кислими відбувається таке через винос 3 грунту кальцію рослинами, вимиванням та внаслідок проявлення ерозійних процесів на наших ерозійнонебезпечних грунтах. Іншою причиною $є$ підкислення фізіологічно кислими мінеральними добривами, особливо азотними, які використовуються найчастіше в найбільшій кількості. Мінімальне внесення органічних добрив та проведення вапнування не зупиняють цей процес. В літературі згадується і про кислотні дощі, що теж впливають на рівень кислотності. Чим кисліший грунт, тим інтенсивніше проявляються негативні властивості. Насамперед це пригнічення корисної мікрофлори, блокування доступності одних елементів мінерального живлення та підвищення рухомості інших, нагромадження рухомих сполук Алюмінію, Феруму, Марганцю. Наявність рухомого алюмінію знижує посухо- та зимостійкість рослин. За даними науковців для кожної сільськогосподарської культури рослин встановлено оптимальне значення pH (табл. 3), яке залежить від грунтово-кліматичних умов, типу грунтів, ї гранулометричного складу, стану окультуреності.

1. Найстійкіші до кислих грунтів бавовник, люцерна, еспарцет, цукрові, столові та кормові буряки, коноплі. Найсприятливіше значення для вирощування приймают $\mathrm{pH} 7-8$.

2. Не рекомендують висаджувати при підвищеному показнику кислотності земель: ячмінь, озима та яра пшениця, кукурудза, соя, квасоля, горох, кормові боби, конюшина, соняшник. Рекомендують для вирощування останніх культур значення рН 6-7.

3. Витриваліі до підвищеної кислотності земель жито, овес, просо, гречка, тимофіївка. Такі рослини переносять грунт із значенням $\mathrm{pH} 4,5-7,5$, проте сприятливіші умови рекомендують $\mathrm{pH}$ 5,5-6,0.

4. Льон і картопля вимагають вапнування тільки дуже кислих грунтів. Картопля добре росте на кислих грунтах, $\mathrm{pH}$ 5,5-6,0.

5. Люпин, жовтий та синій, середела добре ростуть на кислих грунтах, $\mathrm{pH} 4,5-5,5$.

Проаналізувавши дослідження, ми виокремили найістотніші причини, що обумовлюють підкислення грунтів:

1. У грунті мікроорганізми виділяють вуглекислий газ, який у грунтовому розчині утворює карбонатну кислоту;

2. Перетворення окремих органічних решток у гумус, наприклад, хвоя соснових;

3. Поглинання культурами 3 грунтового розчину йонів лужних і лужноземельних металів (Калію, Натрію, Кальцію, Магнію), що підсилює наявність у грунті кислотних утворень;

4. Підживлення грунту кислотоутворюючими добривами, наприклад, аміачні добрива на основі сечови- 
ни. Вони є вихідними речовинами для утворення нітратної кислоти;

5. Опади кислотного характеру. До їх кислотного залишку входять Сульфур, Нітроген, Карбон, Хлор. У атмосфері внаслідок процесу конденсації синтезуєть- ся нітратна, сульфатна, карбонатна хлоридна кислоти. Останні потрапляють на сільськогосподарські землі у складі дощу;

6. Причиною підвищеної кислотності грунту буває і материнська структура грунту.

Таблиця 3

Значення рН для окремих культурних рослин

\begin{tabular}{llll}
\hline Культура & $\mathrm{pH}$ & Культура & $\mathrm{pH}$ \\
\hline Люцерна & $7,2-8,0$ & Конюшина & $6,0-7,0$ \\
Буряки цукрові & $7,0-7,5$ & Соняшник & $6,0-6,8$ \\
Коноплі & $6,7-7,4$ & Бавовник & $6,5-7,3$ \\
Ячмінь & $6,0-7,5$ & Просо & $5,5-7,5$ \\
Пшениця озима & $6,3-7,5$ & Жито & $5,0-7,7$ \\
Пшениця яра & $6,0-7,3$ & Овес & $5,0-7,5$ \\
Кукурудза & $6,0-7,5$ & Гречка & $4,7-7,5$ \\
Соя & $6,5-7,5$ & Льон & $5,5-6,5$ \\
Горох & $6,5-7,0$ & Картопля & $4,5-6,3$ \\
Кормові боби & $6,0-7,0$ & Люпин & $4,6-6,0$ \\
Квасоля & $6,4-7,1$ & Тимофіївка & $4,5-7,6$ \\
Яблуня & $6,5-7,2$ & Цибуля & $6,4-7,9$ \\
Чорна смородина & $6,2-6,7$ & Капуста & $6,7-7,4$ \\
Агрус & $4,6-4,8$ & Морква & $5,5-7,0$ \\
Редис & $5,5-7,3$ & Помідори & $6,3-6,7$ \\
Огірки & $6,4-7,0$ & & \\
\hline
\end{tabular}

\section{Висновки}

Отже, в процесі роботи з'ясували, що основною причиною кислотної деградації грунтів $\epsilon$ вторинне підкислення, що має переважно антропогенне походження. Реакція грунту має великий вплив на ріст $\mathrm{i}$ розвиток рослин, на життєдіяльність корисних мікроорганізмів. мікробіологічні, хімічні й біохімічні процеси грунту. За середньозваженими показниками властивостей грунтів на окремих полях і в господарстві загалом можна зробити різні висновки щодо напряму родючості грунту. Результати досліджень підтверджують, що в сільськогосподарських угіддях Тернопільської області Козівського району фермерського господарства "Вікторія-92" переважають грунти 3 низьким (127 мг/кг) ступенем забезпечення Азоту в сполуках, що лужно гідролізуються, середнім (69 мг/кг грунту) та підвищеним (127 мг/кг) - рухомих фосфатів, високим (125,124 мг/кг грунту) - обмінного Калію. За середньозваженими показниками вмісту гумусу грунти відповідають середньому $(2,41 \%)$ ступеню забезпечення. На території господарства найбільші площі 250,0 га $(81,7 \%)$ займають грунти з нейтральною (рН сол. $>6,0$ ) реакцією грунтового розчину.

Перспективи подальших досліджень. Дані обстеження допоможуть спеціалістам фермерського господарства правильно визначити потребу грунтів в хімічній меліорації, встановити найбільш оптимальні дози органічних та мінеральних добрив, вести планомірну роботу щодо підвищення родючості грунту та урожайності сільськогосподарських культур.

\section{References}

Andriichuk, V.H. (2002). Ekonomika ahrarnykh pidpryiemstv: pidruchnyk. 2-he vyd., dopovn. i pererob. K.g: KNEU (in Ukrainian).

Doklad Konferencii OON po okruzhajushhej srede i razvitiju (1993). Rio-de-Zhanejro, 3-14 ijunja 1992 g. T. 2. Otchet o rabote Konferencii. N'ju-Jork, 19, 31, 40-60, 64, 71 (in Russian).

Horodnyi, M.M. (2004). Naukovo-metodychni rekomendatsii $\mathrm{z}$ optymizatsii mineralnoho zhyvlennia silskohospodarskykh kul-tur ta stratehii udobrennia. K.: TOV Alefa (in Ukrainian).

Hudz, V.P. (2007). Zemlerobstvo z osnovamy gruntoznavstva i ahrokhimii. 2-he vyd. K.: Tsentr uchbovoi literatury (in Ukrainian).

Paranjak, R.P., Kalyn, B.M., \& Gutyj, B.V. (2019). Prospects of transgenic plants in the agro-sphere of Lviv region. Scientific Messenger of Lviv National University of Veterinary Medicine and Biotechnologies. Series: Agricultural sciences, 21(90), 54-58. doi: 10.32718/nvlveta9009.

Ryzhuk, S.M., \& Lisovyi, M.V. (2003). Metodyka ahrokhimichnoi pasportyzatsii zemel silskohospodarskoho pryznachennia. K. (in Ukrainian).

Semchyk, V.I. (2003). Zemelnyi kodeks Ukrainy : nauk.prakt. Komentar. K.: Vydavnychyi Dim In Yure (in Ukrainian).

Vidnoshennia silskohospodarskykh kultur do reaktsii gruntu. Rezhym dostupu: http://pidruchniki.com/ 76163/agropromislovist/vidnoshennya_silskogospodar skih_kultur_reaktsiyi_gruntu (in Ukrainian). 